\title{
Efficacy of probenazole for control of southern corn leaf blight
}

\author{
Ken-Haow YANG, ${ }^{\dagger}$ Chien-Jui HuAng, ${ }^{\dagger}$ Yi-Hung LIU and Chao-Ying CHEN* \\ Department of Plant Pathology and Microbiology, National Taiwan University, \\ No. 1, Sec. 4, Roosevelt Rd., Taipei 10617, Taiwan, Republic of China
}

(Received November 10, 2010; Accepted January 12, 2011)

\begin{abstract}
Southern corn leaf blight (SCLB) is an important foliar disease of maize and its control depends on resistant cultivars or fungicides. Maneb is the recommended fungicide to control SCLB; however, application of maneb has been increasingly limited due to public concerns about the potential harmful effects of fungicide residues on human health and the environment. Therefore, an alternative approach was explored in this study using a plant activator, probenazole, to control SCLB. Application of probenazole provided effective control of SCLB under greenhouse conditions. For practical use, using probenazole at a practical rate $(1.8 \mathrm{~kg}$ a.i./ha) was demonstrated to effectively suppress SCLB under field conditions. In addition, the effect of probenazole treatment on the growth of maize was examined. Compared with the untreated control, leaf length, leaf width, plant height, and the fresh and dry weights of probenazole-treated corn plants were not influenced; therefore, it is suggested that application of probenazole could be an alternative to control SCLB. (C) Pesticide Science Society of Japan
\end{abstract}

Keywords: Cochliobolus heterostrophus; probenazole; plant activator; maneb.

\section{Introduction}

Maize (Zea mays L.), cultivated all over the world, is the third most important cereal crop after wheat and rice. Southern corn leaf blight (SCLB) caused by Cochliobolus heterostrophus (Drechsler) Drechsler (anamorph=Bipolaris maydis (Nisikado) Shoemaker; synonym=Helminthosporium maydis Nisikado) is a widespread disease throughout most hot humid corn-growing areas. SCLB, predominantly caused by race O, is a problem in sweet corn cultivation and seed production in the southern Atlantic coast area of the United States, and causes grain yield losses of $40 \%$ or more. ${ }^{1,2)}$ In Taiwan, $C$. heterostrophus race $\mathrm{O}$ is considered an important foliar pathogen of maize., ${ }^{3,4)}$ Most effective control of SCLB with the recommended protectant fungicide maneb is achieved when maneb is applied as soon as the disease symptom is observed, and reapplied every 4-7 days; however, application of maneb has been increasingly limited due to public concerns about the potential harmful effects of fungicide residues on human health and the environment; ${ }^{5-8)}$ therefore, the possibility of controlling $C$. heterostrophus by alternative approaches

\footnotetext{
* To whom correspondence should be addressed.

E-mail: cychen@ntu.edu.tw

Published online March 27, 2011

(C) Pesticide Science Society of Japan

$\dagger$ These authors contributed equally.
}

needs to be explored.

Probenazole (3-allyloxy-1,2-benzisothiazole-1,1-dioxide) has been widely used against rice blast (caused by Magnaporthe grisea) and bacterial leaf blight (caused by Xanthomonas oryzae pv. oryzae) for more than 30 years. ${ }^{9,10)}$ The effect of probenazole in controlling rice diseases is related to the induction of plant defense. ${ }^{11-18)}$ In our previous studies, applications of probenazole were demonstrated to trigger systemic resistance in lily against Botrytis elliptica and lesion numbers caused by $B$. elliptica were reduced on probenazoletreated lily plants. ${ }^{19,20)}$ The objectives of this study were to evaluate the applications of probenazole to control SCLB on maize under greenhouse and field conditions and to examine the effect of probenazole treatment on the growth of maize.

\section{Materials and Methods}

\section{Plant material}

Seeds of maize cv. Honey Jean No. 3 (Known-You Seed Co., Ltd., Kaohsiung, Taiwan, ROC) were used in this study. For greenhouse experiments, seeds were sown in 12-cm-diameter pots ( 3 seeds per pot) containing potting mix (peat moss, perlite, and vermiculite at a ratio of $5: 2: 2$ ). Plants were grown at $25^{\circ} \mathrm{C}$ with a $16 \mathrm{~h} / 8 \mathrm{~h}$ light/dark cycle for 21 to 28 days. On the other hand, seeds were planted in sandy loam-type soil in the experimental field of National Taiwan University, Taipei, Taiwan, for field experiments. 


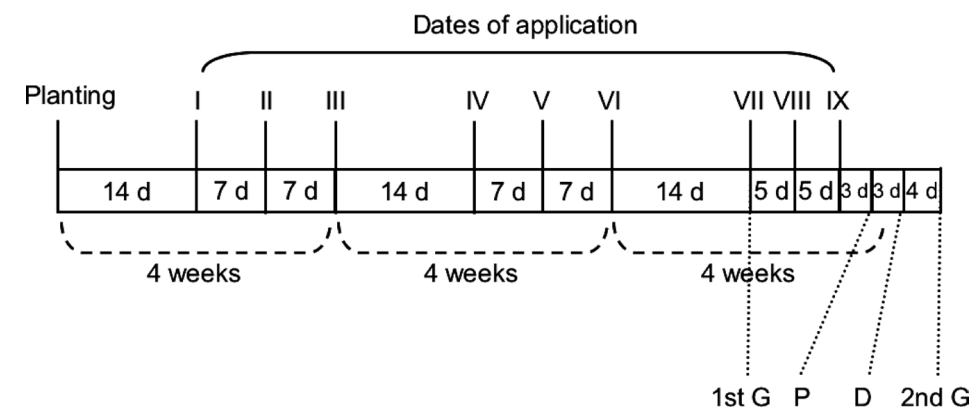

Fig. 1. Schematic diagram of the second field experiment schedule. $\mathrm{P}$ and $\mathrm{D}$ represent pathogen inoculation and disease assessment, respectively.1stG and 2 ndG represent the dates to measure plant growth.

\section{Chemicals}

Probenazole of technical grade (purity 98.8\%) and Oryzemate (6\% active ingredient (a.i): probenazole, granule) were obtained from Meiji Seika Kaisha Ltd. (Tokyo, Japan). Probenazole of technical grade was used for an antifungal activity assay. In disease control experiments, Oryzemate was applied to the soil surface according to the manufacturer's instructions. Fungicide Dithane M-22 (80\% active ingredient: maneb, wettable powder) (Rohm and Haas, Philadelphia, PA, USA) was prepared as a water suspension of $2 \mathrm{~g}$ a.i./1 and applied using a handheld small sprayer at the recommended rate of $2 \mathrm{~kg}$ a.i./ha (i.e. 10001 of Dithane M-22 suspension/ha).

\section{Pathogen inoculation and rating techniques}

C. heterostrophus race $\mathrm{O}$ was cultured and maintained on potato dextrose agar (BD Diagnostic Systems, Sparks, MD, USA) at $25^{\circ} \mathrm{C}$ in the dark. For sporulation, C. heterostrophus was cultured on autoclaved corn leaves at $28^{\circ} \mathrm{C}$ for 1 to 2 weeks in the dark. ${ }^{4,21)} \mathrm{A}$ conidial suspension of $C$. heterostrophus was prepared in $0.5 \mathrm{~g} / 1$ Tween 20 and adjusted to a final concentration of $5 \times 10^{4}$ conidia $/ \mathrm{ml}$ for inoculation. A spore suspension of $C$. heterostrophus was sprayed as a fine mist until running off onto both surfaces of fully expanded leaves of corn plants. The inoculated corn plants were kept under moist condition at $25^{\circ} \mathrm{C}$ for 1 day before they were moved to the greenhouse bench. Two days after inoculation, disease severity was assessed based on a 0 to 4 scale (i.e. 0 , no symptoms; $1,1-25 \% ; 2,26-50 \% ; 3,51-75 \% ; 4,76-100 \%$ leaf area covered with lesions). Disease severity was calculated as the sum of the disease severity scale multiplied by the number of diseased plants in the same category, divided by the total number of tested plants multiplied by 4 and multiplied by 100 .

\section{Disease control assays under greenhouse conditions}

For testing the effective dose of Oryzemate to control SCLB, it was applied at 4,40 , and $400 \mathrm{mg}$ a.i. $/ \mathrm{kg}$ potting mix. One day after application, the leaves were inoculated with a spore suspension of $C$. heterostrophus and disease severity was assessed as described above. Each treatment had 3 replicates and the test was repeated twice.

Furthermore, pots were arranged in a randomized complete block design with 30 replicates per treatment and 3 plants per replicate. Oryzemate was applied at $4 \mathrm{mg}$ a.i./ $\mathrm{kg}$ potting mix 3 times at 5-day intervals. Dithane M-22 (2 kg a.i./ha) was sprayed until running off onto both surfaces of fully expanded leaves 3 times at 5-day intervals to serve as a positive control. One day after the last application, the leaves were inoculated with a spore suspension of $C$. heterostrophus and disease severity was subsequently assessed as described above. The test was repeated once.

\section{Field experiments of disease control}

Field experiments were performed in the experimental field of National Taiwan University. In the first experiment, corn plants were grown in sandy loam-type soil at 33 and $23^{\circ} \mathrm{C}$ average day and night temperature with 71 to $77 \%$ relative humidity, and 11 to $12 \mathrm{~h}$ day length. Plots $\left(1 \mathrm{~m}^{2}\right.$ each) were arranged in a randomized complete block design with 15 replicates for each treatment. Oryzemate was applied at $1.8 \mathrm{~kg}$ a.i./ha 3 times at 5-day intervals. Dithane M-22 (2 kg a.i./ha) was sprayed until running off onto both surfaces of fully expanded leaves 3 times at 5-day intervals to serve as a positive control. Three days after the last application, the leaves were inoculated with a spore suspension of C. heterostrophus and disease severity was assessed 3 days after inoculation. The test was repeated once.

In the second experiment, plots $\left(1 \mathrm{~m}^{2}\right.$ each) were arranged in a randomized complete block design with 35 replicates for each treatment. Schematic diagram of the schedule to apply Oryzemate and Dithane M-22 is presented in Fig. 1 as shown in a previous report ${ }^{21)}$. Disease severity was assessed 3 days after inoculation. The test was repeated once.

\section{Assay of the effect of Oryzemate on plant growth}

In the second field experiment, 5 parameters of plant growth (leaf length, leaf width, plant height, and fresh and dry weights of plants) of different treatments were measured before and after inoculation with $C$. heterostrophus at the time points as indicated in Fig. 1. 
7. Assay of the effect of probenazole on conidial germination and mycelial growth of $C$. heterostrophus

The effect of probenazole against conidial germination of $C$. heterostrophus was assayed by the method of Huang et al. ${ }^{22)}$ with a slight modification. Assay mixtures contained $10 \mu \mathrm{l}$ of the conidial suspension of $C$. heterostrophus $\left(1 \times 10^{5}\right.$ coni$\mathrm{dia} / \mathrm{ml}$ ) and an equal volume of a probenazole solution in $100 \mathrm{mM}$ potassium phosphate buffer ( $\mathrm{pH}$ 6.0). In the control, only $100 \mathrm{mM}$ potassium phosphate buffer ( $\mathrm{pH} 6.0$ ) was used instead of the test solution. Conidial germination was examined under a light microscope and the percentage of inhibition was calculated after incubation of prepared assay mixtures at $25^{\circ} \mathrm{C}$ for $12 \mathrm{~h}$. Each assay was performed in triplicate.

On the other hand, probenazole was added to molten malt extract agar (MEA; BD Diagnostic Systems, Sparks, MD, USA) at final concentrations of 0,40 , and $200 \mu \mathrm{g} / \mathrm{ml}$. Mycelial discs of $C$. heterostrophus were placed at the center of MEA plates containing different concentrations of probenazole. Diameters of colonies were measured and the percentage of inhibition was calculated after incubation at $28^{\circ} \mathrm{C}$ for 3 days in the dark. Each assay was performed in triplicate.

\section{8. $\quad$ Statistical analysis}

The data obtained were subjected to the standard analysis of variance (ANOVA) procedure with SAS software (SAS Institute, Cary, NC, USA). Fisher's protected least significant difference values at $P<0.05$ were used to separate treatment means when ANOVA indicated a significant $F$ values.

\section{Results}

\section{Control of SCLB by application of Oryzemate under greenhouse conditions}

To investigate whether Oryzemate effectively induced systemic resistance against $C$. heterostrophus in maize, Oryzemate at various doses was applied for disease control assays. Compared with disease control, maize was protected significantly from $C$. heterostrophus infection by application of Oryzemate at 4,40 , and $400 \mathrm{mg}$ a.i./ $/ \mathrm{kg}$ potting mix, especially $4 \mathrm{mg}$ a.i./kg potting mix (Fig. 2). Nevertheless, when Oryzemate exceeded $40 \mathrm{mg}$ a.i./ $/ \mathrm{kg}$ potting mix, the protection effect decreased as shown by an increase in disease severity. Thus, Oryzemate was applied at a dose of $4 \mathrm{mg}$ a.i./kg potting mix in further experiment. Figure 3 shows the effect of Oryzemate to protect maize from $C$. heterostrophus under greenhouse conditions. Compared with the untreated control, maize could be protected from $C$. heterostrophus infection by application of Oryzemate; however, the effect of Oryzemate to control SCLB was less than that of Dithane M-22 and had a significant difference (Fig. 3).

\section{Control of SCLB by application of Oryzemate under field conditions}

Figure 4 shows the effect of Oryzemate to protect maize from C. heterostrophus under field conditions. In the first field

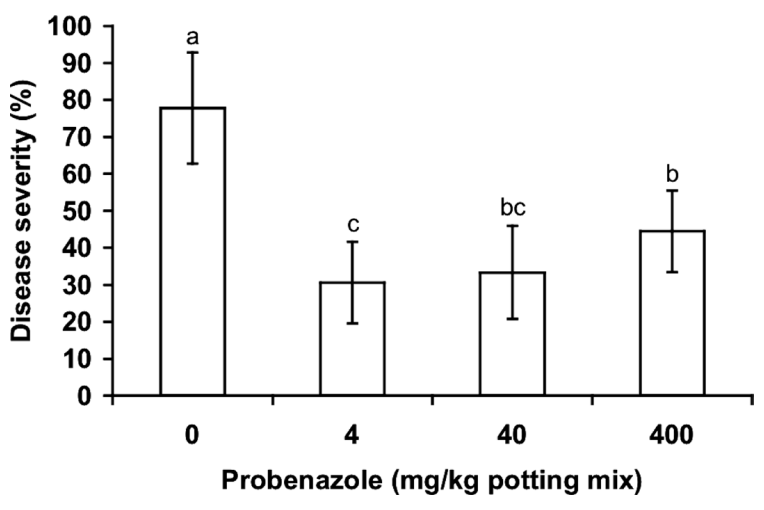

Fig. 2. Effective doses of probenazole to protect maize from SCLB. Oryzemate was applied at doses of 40,400 , or $4000 \mathrm{mg}$ per pot, which was equivalent to probenazole at doses of 4,40 , or $400 \mathrm{mg} / \mathrm{kg}$ potting mix. Data are the means \pm standard error. Different letters above bars indicate significant differences among treatments $(P<0.05)$.

experiment, maize was significantly protected from SCLB by application of Oryzemate 3 times. The effect of Oryzemate to control SCLB was less than the application of Dithane M-22 with a significant difference (Fig. 4). In the second field experiment, a schedule (as presented in Fig. 1) was followed to apply Oryzemate and Dithane M-22, and their effects to control SCLB were evaluated. Both Oryzemate and Dithane M22 were applied 9 times during 12 weeks. Oryzemate significantly protected maize from $C$. heterostrophus infection; however, the protection effect of Oryzemate was less than that of Dithane M-22 and a significant difference existed between these treatments (Fig. 4).

\section{Effect of Oryzemate on the growth of maize}

Furthermore, detailed analysis of the effect of Oryzemate on the growth of maize was performed in the second field experiment. Before inoculation with C. heterostrophus, application of Oryzemate did not interfere with the growth of maize and the growth levels as measured on leaf length, leaf width, plant height, fresh weight, and dry weight, were not

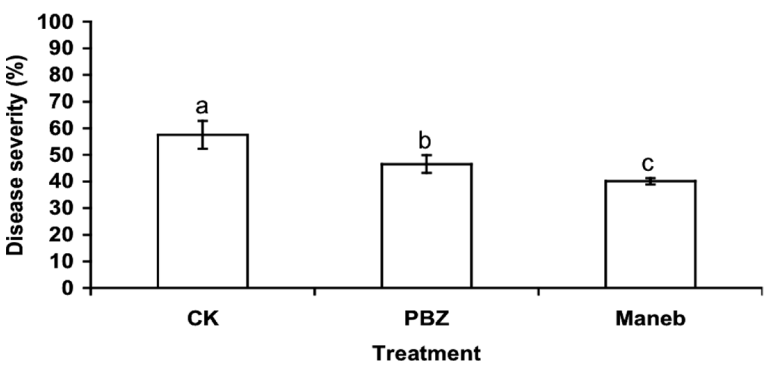

Fig. 3. Suppression of southern corn leaf blight by Oryzemate under greenhouse conditions. Maneb, treatment with Dithane M-22, the recommended fungicide against $C$. heterostrophus. PBZ, treatment with Oryzemate; CK, disease control. Data are the means \pm standard error. Different letters above bars indicate significant differences among treatments $(P<0.05)$. 


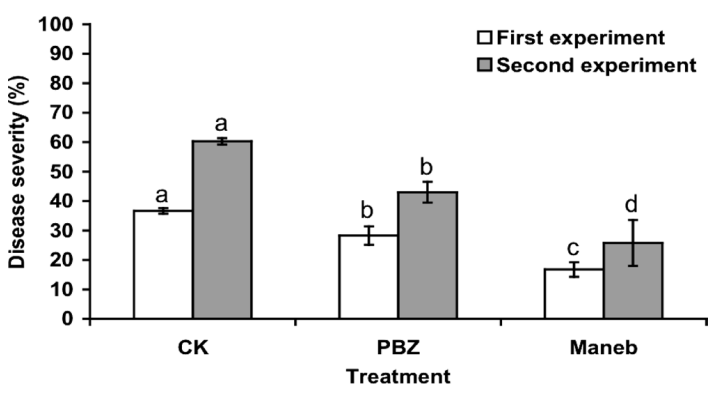

Fig. 4. Suppression of southern corn leaf blight by Oryzemate under field conditions. Two field experiments were performed. Maneb, treatment with Dithane M-22, the recommended fungicide against $C$. heterostrophus. PBZ, treatment with Oryzemate; CK, disease control. Data are the means \pm standard error. Data in the same experiment indicated by different letters above bars were significantly different $(P<0.05)$.

significantly different from that of the untreated control (Table 1). After inoculation with $C$. heterostrophus, the growth of Oryzemate-treated maize was also not significantly different from that of the untreated control (Table 2). The data indicated that application of Dithane M-22 caused a slight decrease of maize growth as shown in the fresh and dry weights of plants (Table 1,2).

\section{Effect of probenazole on C. heterostrophus}

The effects of probenazole on conidial germination and mycelial growth of $C$. heterostrophus were investigated. As shown in Table 3, conidial germination of $C$. heterostrophus was significantly inhibited by $200 \mu \mathrm{g} / \mathrm{ml}$ probenazole. When the concentration of probenazole was reduced to $40 \mu \mathrm{g} / \mathrm{ml}$, about $50 \%$ conidial germination was inhibited. However, mycelial growth of $C$. heterostrophus was not effectively inhibited by probenazole despite using $200 \mu \mathrm{g} / \mathrm{ml}$.

\section{Discussion}

In this study, Oryzemate was demonstrated to protect maize

Table 1. Effect of Oryzemate on plant growth before fungal inoculation

\begin{tabular}{lrrr}
\hline & \multicolumn{3}{c}{ Treatment $^{b)}$} \\
\cline { 2 - 4 } Parameter $^{a)}$ & Untreated & Oryzemate & Dithane M-22 \\
\hline Leaf length & $30.8 \pm 1.0$ & $32.2 \pm 2.7$ & $32.4 \pm 1.5$ \\
Leaf width & $4.5 \pm 0.2$ & $3.7 \pm 0.5$ & $3.8 \pm 0.2$ \\
Plant height & $46.3 \pm 7.1$ & $44.4 \pm 5.0$ & $44.0 \pm 1.3$ \\
Fresh weight & $32.7 \pm 1.6$ & $31.4 \pm 1.5$ & $24.9 \pm 1.3$ \\
Dry weight & $9.7 \pm 0.6$ & $9.7 \pm 0.6$ & $8.6 \pm 0.5$ \\
\hline
\end{tabular}

a) Units of parameters: leaf length, width, and plant height: $\mathrm{cm}$; fresh and dry weights: g. ${ }^{b)}$ Data were measured before fungal inoculation (10 weeks after planting).
Table 2. Effect of Oryzemate on plant growth after fungal inoculation

\begin{tabular}{lrrr}
\hline & \multicolumn{3}{c}{ Treatment $^{b)}$} \\
\cline { 2 - 4 } Parameter $^{a)}$ & Untreated & Oryzemate & Dithane M-22 \\
\hline Leaf length & $32.0 \pm 0.8$ & $31.6 \pm 0.7$ & $32.5 \pm 1.7$ \\
Leaf width & $4.8 \pm 1.0$ & $3.7 \pm 0.5$ & $3.8 \pm 0.3$ \\
Plant height & $55.9 \pm 1.8$ & $51.9 \pm 2.6$ & $54.1 \pm 1.4$ \\
Fresh weight & $36.8 \pm 1.2$ & $35.1 \pm 0.4$ & $27.5 \pm 1.2$ \\
Dry weight & $10.2 \pm 1.0$ & $10.0 \pm 1.2$ & $8.6 \pm 0.2$ \\
\hline
\end{tabular}

a) Units of parameters: leaf length, width, and plant height: $\mathrm{cm}$; fresh and dry weights: g. ${ }^{b)}$ Data were measured after fungal inoculation (13 weeks after planting).

from SCLB caused by $C$. heterostrophus race $\mathrm{O}$ under greenhouse and field conditions (Figs. 2-4). Maize was protected significantly from $C$. heterostrophus infection by application of Oryzemate at a dose of $4 \mathrm{mg}$ a.i./kg potting mix (Fig. 2). When Oryzemate exceeded $40 \mathrm{mg}$ a.i./kg potting mix, the protection effect decreased. A similar phenomenon was reported as systemic resistance of plants was induced by an SAR elicitor. ${ }^{23-25)}$ According to the study of Trotel-Aziz et al., application of chitosan at higher concentrations caused leaf tissue to appear damaged. ${ }^{25}$ ) Thus, we suggest that the application of a higher dose of Oryzemate (above $40 \mathrm{mg}$ a.i./kg potting mix) might cause leaf tissue damage, as shown by an increase in disease severity.

Compared with Dithane M-22, a low rate of Oryzemate (1.8 kg a.i./ha) could provide maize sufficient protection

Table 3. Effect of probenazole on conidial germination and mycelial growth of Cochliobolus heterostrophus

\begin{tabular}{ccccc}
\hline $\begin{array}{c}\text { Probenazole } \\
(\mu \mathrm{g} / \mathrm{ml})\end{array}$ & $\begin{array}{c}\text { Inhibition of conidial } \\
\text { germination }(\%)^{a)}\end{array}$ & $\begin{array}{c}\text { Mycelial growth } \\
(\mathrm{mm})^{b)}\end{array}$ \\
\hline 0 & $0 \pm 0$ & $\mathrm{a}^{c)}$ & $21.3 \pm 1.3$ & $\mathrm{a}$ \\
40 & $47 \pm 16$ & $\mathrm{~b}$ & $19.5 \pm 0.5$ & $\mathrm{a}$ \\
200 & $99 \pm 1$ & $\mathrm{c}$ & $17.0 \pm 1.0$ & $\mathrm{~b}$ \\
\hline
\end{tabular}

a) Assay mixtures contained $10 \mu 1$ of conidial suspension of $C$. heterostrophus $\left(1 \times 10^{5}\right.$ conidia/ml $)$ and an equal volume of probenazole solution in $100 \mathrm{mM}$ potassium phosphate buffer (pH 6.0). In the control, the buffer was used instead of test solution. Conidial germination was examined under a light microscope after incubation of prepared assay mixtures at $25^{\circ} \mathrm{C}$ for $12 \mathrm{~h}$ and the percentage of inhibition was calculated. ${ }^{b}$ Mycelial discs of $C$. heterostrophus were placed at the center of MEA plates containing different concentrations of probenazole. Diameters of colonies were measured after incubation at $28^{\circ} \mathrm{C}$ for 3 days in the dark. ${ }^{c)}$ Data in the same column followed by different letters are significantly different $(P<0.05)$. 
against $C$. heterotrophus (Fig. 4). In addition, Oryzemate did not interfere with the growth of maize (Tables 1,2) and no phytotoxic effect of Oryzemate has been observed; therefore, it is suggested that the application of Oryzemate could be a low-toxicity and highly efficient alternative to control SCLB.

In addition, SCLB is often considered a late-season disease of maturing maize plants, usually not developing until postanthesis, the grain-expanding period. ${ }^{2)}$ According to the results of two field experiments (Fig. 4), Oryzemate effectively controlled SCLB in 4- and 12-week-old maize plants. Twelveweek-old maize is in growth stage 6 or 7 , the late growth stage. $^{2)}$ Thus, the results indicate that application of Oryzemate is a good way to control SCLB from the early to late growth stage of maize.

A low concentration of probenazole $(40 \mu \mathrm{g} / \mathrm{ml})$ only inhibited about $50 \%$ conidial germination but did not reduce the mycelial growth of $C$. heterostrophus. Probenazole effectively inhibited conidial germination of $C$. heterostrophus at a higher concentration $(200 \mu \mathrm{g} / \mathrm{ml})$ but mycelial growth of $C$. heterostrophus was slightly reduced by probenazole (Table 3 ). In addition, a low dose of Oryzemate $(1.8 \mathrm{~kg}$ a.i./ha) was applied to control SCLB and did not contact the pathogen directly by a soil-surface application. In accordance with previous studies, ${ }^{10,11,13,14,18,19,20,26)}$ it is suggested that the effect of Oryzemate to control SCLB could be attributed to the activation of systemic resistance in maize.

Oryzemate is a plant activator and quite effective against blast disease when applied to the root system of rice plants. ${ }^{26,27)}$ Oryzemate has been widely used against rice blast by Japanese farmers since 1975 to provide good, long-lasting control in the paddy fields or nursery boxes. ${ }^{26,27)}$ The persistent activity of Oryzemate was attributed to the host-mediated defense action. ${ }^{11-18)}$ Despite extensive use of Oryzemate over many years, development of resistance in the target fungus has not been observed ${ }^{26}$; thus, using Oryzemate to control SCLB may reduce the outbreak of $C$. heterostrophus due to the development of resistant strains.

Dithane M-22 is an organomanganic fungicide that belongs to the dithiocarbamates family. Dithane M-22, a non-systemic protectant fungicide, has to be sprayed onto the leaf surface to prevent fungal spores from germinating and penetrating the plant. Since non-systemic protectant fungicides can be washed off the foliage by rainfall (or sprinkler irrigation), regular use of Dithane M-22 (2.0-2.4 kg a.i./ha) once every week is recommended to achieve optimal protection against SCLB in Taiwan; however, this is not economically feasible because of the high application costs and the need for frequent applications. In addition, Dithane M-22 is phytotoxic to a number of plants, especially under hot conditions. ${ }^{28)}$ Moreover, its application on crops has been limited by the Environmental Protection Agency of the United States and banned on sweet corn because of potential risks to human health and the environ- ment. As reported, permanent parkinsonism impacted people with chronic exposure to pesticides such as Dithane M-22. ${ }^{7,8)}$

Since Oryzemate is easily purchased in local markets, using Oryzemate to control SCLB could be a low-toxicity, convenient-use and highly efficient alternative.

\section{Acknowledgements}

This study was supported by the Council of Agriculture, Taiwan, Republic of China.

\section{References}

1) A. J. Ullstrup: Annu. Rev. Phytopathol. 10, 37-50 (1972).

2) D. G. White, "Compendium of Corn Disease," 3rd Ed., The American Phytopathological Society, St. Paul, USA, 1999.

3) W. H. Tsai, J. N. Tsai and H. S. Lu: Plant Pathol. Bull. 2, 26-32 (1993).

4) W.-S. Wu and B.-C. Wang: Plant Prot. Bull. 29, 13-24 (1987).

5) S. Costello, M. Cockburn, J. Bronstein, X. Zhang and B. Ritz: Am. J. Epidemiol. 169, 919-926 (2009).

6) D. A. Drechsel and M. Patel: Free Radic. Biol. Med. 44, 1873-1886 (2008).

7) H. B. Ferraz, P. H. F. Bertolucci, J. S. Pereira, J. G. C. Lima and L. A. F. Andrade: Neurology 38, 550-553 (1988).

8) G. Meco, V. Bonifati, N. Vanacore and E. Fabrizio: Scand. J. Work Environ. Health 20, 301-305 (1994).

9) T. Watanabe: J. Pestic. Sci. 2, 395-404 (1977).

10) T. Watanabe, H. Igarashi, K. Matsumoto, S. Seki, S. Mase and Y. Sekizawa: J. Pestic. Sci. 2, 291-296 (1977).

11) M. Iwata, Y. Suzuki, T. Watanabe, S. Mase and Y. Sekizawa: Ann. Phytopathol. Soc. Jpn. 46, 297-306 (1980).

12) N. Midoh and M. Iwata: Plant Cell Physiol. 37, 9-18 (1996).

13) E. Minami and I. Ando: J. Pestic. Sci. 19, 79-83 (1994).

14) Y. Sekizawa and S. Mase: J. Pestic. Sci. 6, 91-94 (1981).

15) Y. Sekizawa, M. Shimura, A. Suzuki and M. Iwata: Agric. Biol. Chem. 445, 1437-1439 (1981).

16) M. Shimura, M. Iwata, N. Tashiro, Y. Sekizawa, Y. Suzuki, S. Mase and T. Watanabe: Agric. Biol. Chem. 45, 1431-1435 (1981).

17) M. Shimura, S. Mase, M. Iwata, A. Suzuki, T. Watanabe, Y. Sekizawa, T. Sasaki, K. Furihata, H. Seto and N. Otake: Agric. Biol. Chem. 47, 1983-1989 (1983).

18) T. Watanabe, Y. Sekizawa, M. Shimura, Y. Suzuki, K. Matsumoto, M. Iwata and S. Mase: J. Pestic. Sci. 4, 53-59 (1979).

19) Y. Y. Lu and C. Y. Chen: Plant Pathol. Bull. 7, 134-140 (1998).

20) Y. Y. Lu, Y. H. Liu and C. Y. Chen: Plant Sci. 172, 913-919 (2007).

21) C. J. Huang, K. H. Yang, Y. H. Liu, Y. J. Lin and C. Y. Chen: Ann. Appl. Biol. 157, 45-53 (2010).

22) C. J. Huang, T. K. Wang, S. C. Chung and C. Y. Chen: J. Biochem. Mol. Biol. 38, 82-88 (2005).

23) S. Farouk, K. M. Ghoneem and A. A. Ali: Egypt. J. Phytopathol. 36, 95-111 (2008).

24) S. Molinari and N. Baser: Crop Prot. 29, 1351-1362 (2010).

25) P. Trotel-Aziz, M. Couderchet, G. Vernet and A. Aziz: Eur. J. Plant Pathol. 114, 405-413 (2006).

26) M. Iwata: Pestic. Outlook 12, 28-31 (2001).

27) I. Yamaguchi and M. Fujimura: J. Pestic. Sci. 30, 67-74 (2005).

28) R. A. Conover: Proc. Fla. State Hort. Soc. 69, 198-200 (1956). 